\title{
Migrant health in Saudi Arabia during the COVID-19 pandemic
}

Mohamed Abdelghafour Ali, ${ }^{1}$, Abdullah Murhaf Al-Khani ${ }^{1}$ and Laila Awad Sidahmed ${ }^{2}$

${ }^{1}$ College of Medicine, Sulaiman Al Rajhi University, Bukairyah, Saudi Arabia. ${ }^{2}$ College of Medicine, Al-Rayan Medical Colleges, Medina, Saudi Arabia. (Correspondence to: Mohamed Abdelghafour Ali: m.ali@sr.edu.sa).

Keywords: Saudi Arabia, migrant, COVID-19, SARS-COV-2

Citation: Ali MA; Al-Khani AM; Sidahmed LA. Migrant health in Saudi Arabia during the COVID-19 pandemic. East Mediterr Health J. 2020;26(8):879880. https://doi.org/10.26719/emhj.20.094

Received: 06/05/20; accepted: 13/07/20

Copyright (c) World Health Organization (WHO) 2020. Open Access. Some rights reserved. This work is available under the CC BY-NC-SA 3.o IGO license (https://creativecommons.org/licenses/by-nc-sa/3.o/igo).

The world is currently living under the era of COVID-19, marked by its heavy toll on international economies and modern lifestyles due to imposed quarantine and curfew regulations. Measures taken to prevent viral transmission in the population should not undervalue the importance of international migrant workers. This particular group is known to have a high risk of occupational and health hazards, along with health-care givers, patients and other essential workers. Worldwide, there are currently an estimated 258 million migrants, many of whom have to pay for health care out-of-pocket. This raises the possibility of not seeking immediate health care and run the risk of spreading the infection. Furthermore, there is a dearth of information on migrant health during the current COVID-19 pandemic in the literature.

Saudi Arabia attracts many migrant workers from low-income countries. It was estimated that during 2019, legally resident foreign workers made up a little more than two-thirds $(67.3 \%)$ of the total work force in Saudi Arabia (excluding undocumented workers and those working in the security and military sectors) (1). Patients who are international migrant workers are at an increased risk of many health issues, including mental health deterioration, all of which necessitate training of health professionals to care for mental health problems of isolated patients (2). Recent studies have shown alarming prevalence of mental issues, namely depression in migrant health workers in Saudi Arabia (3), primarily due to the fear of job insecurity (4). Within the current situation of COVID-19, it is imperative that governments maintain a clear policy regarding health and job security for their international labour, to ensure psychosocial stability and public health.

Saudi Arabia saw its first COVID-19 case identified in Qatif, Eastern Region, on 2 March 2020. In response, the Saudi government imposed a lockdown of Qatif Region on 5 March 2020, including limitation of domestic travel, closure of schools and universities, a shutdown of nonessential industrial facilities, followed by a suspension of international flights on 21 March (5). By 29 June 2020 there was a recorded total of 57719 active cases in Saudi Arabia alone, 127118 recoveries and 1599 deaths (6).

In the current COVID-19 pandemic, Saudi Arabia took the initiative by offering free screening and health-care services for all its residents, including migrant workers.
This included access to treatment, with dedicated teams to deliver supportive treatment to the homes of both migrants and nationals (7). The Saudi Ministry of Health $(\mathrm{MoH})$ has had to take into account the religious observations of Hajj and Umrah - two major gatherings in Saudi Arabia where citizens, migrants and international visitors may gather - and the effect on transmission of respiratory infections. In addition, international migrant workers are often housed in relatively small and crowded accommodation, which provides an environment for greater risk of infection transmission (8). In response, the $\mathrm{MoH}$ has dispensed field units to many neighbourhoods where crowding was evident. This resulted in increased rates of COVID-19 detection in asymptomatic individuals (9). As of 29 June 2020 , the total number of field screening tests was 1591141 (6).

The COVID-19 pandemic has exerted its toll on the working population, including migrant workers. Many industrial factories and non-essential workshops have closed, putting monetary strain on migrants who rely on daily or monthly wages for survival. Migrant workers commonly work at petrol stations, grocery shops, fast food restaurants, industrial workshops and hospitals - all areas where there is a potential for acquiring and transmitting COVID-19. Migrant workers are also found in more domestic environments such as maids, cleaners and personal drivers. Moreover, the sight of many foreign workers outside during curfew may propagate fear and discrimination against such vulnerable populations, specifically international migrant workers.

The media's recent reporting of infection incidence among nationals and the foreign workforce should not be interpreted as discriminatory. Many of the workforce facing the outbreak in hospitals, namely nurses and physicians, are non-Saudi citizens, as is the case in many essential occupations, and therefore reporting of infection rates reflects this demographic reality. Since the commencement of active screening, an increasing number of foreign workers have been confirmed positive with COVID-19 (10). However, because of the availability of accessible health care, more migrant workers are willing to participate in screening, with a focus of testing in high density residences and workers in essential occupations. 
Saudi Arabia has also allocated resources for testing of undocumented migrants, since they are an important group at risk of acquiring and spreading COVID-19 (11). Recognizing the many health-care risks facing illegal migrants, mitigating the transmission of disease and provide access to those in desperate need is the priority for the benefit of society as a whole (12). In addition to local care, Saudi Arabia has extended its reach towards regional support of the Eastern Mediterranean Region with medical supplies, alongside the United Arab Emirates and Qatar (13). This is a step forward beyond national gain and more towards international solidarity in these difficult times.

In conclusion, the ever-evolving COVID-19 pandemic has proved to be an unprecedented challenge to all health-care systems worldwide. Saudi Arabia's approach has been to facilitate access to health care services for all residents, legal and illegal workers. This approach is unprecedented as it is important, since an effective response to the pandemic is only as strong as the weakest link, which here is the vulnerable migrant population.

\section{References}

1. General Authority for Statistics (GASTAT). Employment rate 2019. Riyadh: GASTAT; 2020 (https://www.stats.gov.sa/en/821-0).

2. Lima CKT, Carvalho PMM, Lima I, Nunes J, Saraiva JS, de Souza RI, et al. The emotional impact of Coronavirus 2019-nCoV (new Coronavirus disease). Psychiatry Res. 2020;287:112915.

3. Zaghloul MS, Saquib J, AlMazrou A, Saquib N. Mental health status of expatriate nurses in Northcentral Saudi Arabia. J Immigr Minor Health. 2019;21(6):1233-40.

4. Saquib J, Taleb M, AlMeimar R, Alhomaidan HT, Al-Mohaimeed A, AlMazrou A, et al. Job insecurity, fear of litigation, and mental health among expatriate nurses. Arch Environ Occup Health. 2020;75(3):144-51.

5. Al-Tawfiq JA, Memish ZA. COVID-19 in the Eastern Mediterranean Region and Saudi Arabia: prevention and therapeutic strategies. Int J Antimicrob Agents. 2020 May;55(5):105968. doi: 10.1016/j.ijantimicag.2020.105968

6. Ministry of Health. Coronavirus Disease 2019 (COVID-19) dashboard. Riyadh: Ministry of Health; 2020 (https://covid19.moh.gov. $\mathrm{sa} /)$.

7. Volunteer scout teams contribute to delivering medicines to patients in their homes [in Arabic]. Saudi Press Agency, 2 May 2020 (https://www.spa.gov.sa/viewfullstory.php?lang=ar\&newsid=2081435).

8. Keim-Malpass J, Spears Johnson C, Quandt S, Arcury T. Perceptions of housing conditions among migrant farmworkers and their families: implications for health, safety and social policy. Rural and Remote Health 2015; 15: 3076. (https://www.rrh.org.au/ journal/article/3076).

9. Nugali N. Saudi Arabia's active mass testing contains COVID-19 spread. Arab News, 21 April 2020. (https://arab.news/6n4mx).

10. Health Ministry spokesperson hails the advantage of active screening. Saudi Press Agency, 2 April 192020 (https://www.spa.gov. sa/viewfullstory.php?lang=en\&newsid=2076445).

11. Bhopal R. Covid-19: undocumented migrants are probably at greatest risk. BMJ. 2020;369:m1673. https://doi.org/10.1136/bmj. m1673

12. Hargreaves S, Kumar BN, McKee M, Jones L, Veizis A. Europe's migrant containment policies threaten the response to covid-19. BMJ. 2020;368:m1213. https://doi.org/10.1136/bmj.m1213

13. Al-Mandhari A; Kodama C; Abubakar A; Brennan R. Solidarity in response to COVID-19 outbreak in the Eastern Mediterranean Region. East Mediterr Health J. 2020;26(5):492-494. https://doi.org/10.26719/2020.26.5.492 